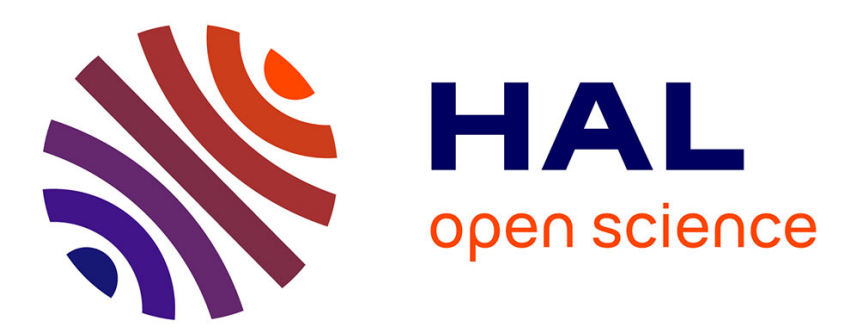

\title{
A PPAR-independent pathway to PUFA-induced COX-2 expression
}

\author{
K. Derecka, E.L. Sheldrick, D.C. Wathes, D.R.E. Abayasekara, A.P.F. Flint
}

\section{To cite this version:}

K. Derecka, E.L. Sheldrick, D.C. Wathes, D.R.E. Abayasekara, A.P.F. Flint. A PPAR-independent pathway to PUFA-induced COX-2 expression. Molecular and Cellular Endocrinology, 2008, 287 (1-2), pp.65. 10.1016/j.mce.2008.02.015 . hal-00532004

\section{HAL Id: hal-00532004 https://hal.science/hal-00532004}

Submitted on 4 Nov 2010

HAL is a multi-disciplinary open access archive for the deposit and dissemination of scientific research documents, whether they are published or not. The documents may come from teaching and research institutions in France or abroad, or from public or private research centers.
L'archive ouverte pluridisciplinaire HAL, est destinée au dépôt et à la diffusion de documents scientifiques de niveau recherche, publiés ou non, émanant des établissements d'enseignement et de recherche français ou étrangers, des laboratoires publics ou privés. 


\section{Accepted Manuscript}

Title: A PPAR-independent pathway to PUFA-induced COX-2 expression

Authors: K. Derecka, E.L. Sheldrick, D.C. Wathes, D.R.E. Abayasekara, A.P.F. Flint

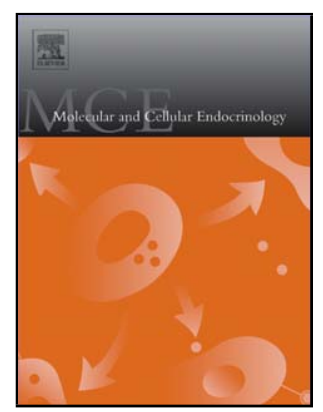

PII:

S0303-7207(08)00087-7

DOI: doi:10.1016/j.mce.2008.02.015

Reference: MCE 6824

To appear in: Molecular and Cellular Endocrinology

Received date: $5-10-2007$

Revised date: $15-2-2008$

Accepted date: $16-2-2008$

Please cite this article as: Derecka, K., Sheldrick, E.L., Wathes, D.C., Abayasekara, D.R.E., Flint, A.P.F., A PPAR-independent pathway to PUFAinduced COX-2 expression, Molecular and Cellular Endocrinology (2007), doi:10.1016/j.mce.2008.02.015

This is a PDF file of an unedited manuscript that has been accepted for publication. As a service to our customers we are providing this early version of the manuscript. The manuscript will undergo copyediting, typesetting, and review of the resulting proof before it is published in its final form. Please note that during the production process errors may be discovered which could affect the content, and all legal disclaimers that apply to the journal pertain. 


\title{
A PPAR-independent pathway to PUFA-induced COX-2 expression
}

(1)

\author{
K. DERECKA, E. L. SHELDRICK, D. C. WATHES ${ }^{\text {a }}$, D. R. E. ABAYASEKARA ${ }^{\mathrm{a}}$, AND
} A.P.F. FLINT ${ }^{1}$
Division of Animal Physiology, School of Biosciences, University of Nottingham, Sutton Bonington Campus, Loughborough, Leics LE12 5RD, UK and ${ }^{a}$ Reproduction, Genes and Development Group, Royal Veterinary College, Hawkshead Lane, North Mymms, Hatfield, Herts AL9 7TA, UK

\section{Running title: PUFAs, PPARs and COX-2}

${ }^{1}$ Corresponding author: Division of Animal Physiology, School of Biosciences, University of Nottingham, Sutton Bonington Campus, Loughborough, Leicestershire LE12 5RD, UK. Tel.: +44 115 9516301; fax: +44 115 9516302. Email address: Anthony.Flint@nottingham.ac.uk 
39 Keywords: Arachidonic acid; Protein kinase C; Peroxisome-proliferator-activated receptor;

40 Cyclooxygenase 2; (Bovine endometrium).

45 Summary

46 Polyunsaturated fatty acids (PUFAs) induce COX-2 in bovine endometrial stromal cells

47 through activation of peroxisome-proliferator-activated receptor alpha (PPAR $\alpha$ ). We have 48 investigated alternative (PPAR-independent) pathways to COX-2 induction using a reporter

49 construct driven by a $C O X-2$ gene promoter sequence lacking a PPAR response element. This 50 construct was induced by PUFAs, but not by PPAR agonists. PPAR-independent reporter gene 51 expression occurred $6 \mathrm{~h}$ after PPAR-dependent induction of the endogenous COX-2 gene. In 52 contrast to PPAR-dependent COX-2 induction, which is not affected by NF- $\kappa \mathrm{B}$ inhibitors, the 53 PPAR-independent pathway was blocked by the NF- $\kappa B$ inhibitor MG132 or following deletion 54 of NF- $\kappa \mathrm{B}$ sites in the $C O X-2$ promoter. The PPAR-independent effect of PUFA was mimicked 55 by the PKC activators $4 \beta$-PMA and prostaglandin $\mathrm{F}_{2 \alpha}$, but was not blocked by the PKC 56 inhibitor RO318425. The results demonstrate a pathway to the induction of COX-2 by PUFAs 57 requiring $\mathrm{NF}-\kappa \mathrm{B}$ but not PPAR or PKC. 


\section{INTRODUCTION}

60 Various hormones interact with G-protein-linked cell surface receptors to activate 61 phospholipases and raise intracellular levels of polyunsaturated fatty acids (PUFAs). A good example is the effect of oxytocin exerted via oxytocin receptors on the epithelium of the uterine endometrium, which leads to activation of phospholipases $\mathrm{C}$ and $\mathrm{A}$, releasing arachidonic acid and other PUFAs esterified in phospholipids (Flint et al., 1986). PUFAs produced in this way may then act as second messengers, both through activation of protein kinases and via other metabolic products (Khan et al., 1995; Maloberti et al., 2005).

PUFAs may also be secreted by the cells in which they are generated, to act on neighbouring cells as paracrine messengers (Cooke et al., 1991; Ronco et al., 2002). This has been suggested to occur in the endometrium in relation to both activation of cyclic AMP phosphodiesterase (Cheng et al., 2007) and induction of cyclooxygenase 2 (COX-2; also known as prostaglandin endoperoxide synthase 2; Sheldrick et al., 2007). Evidence for an effect on COX-2 includes the observations that PUFAs raise COX-2 levels in rat uterine stromal cells (Prigent-Tessier et al., 1996) and in bovine endometrial epithelial cells (Parent et al., 2003) through increased COX-2 gene expression and increased levels of COX-2 transcripts (Asselin et al., 1997; Meade et al., 1999). Furthermore the oxytocin receptor is expressed in the bovine endometrial epithelium at a time when it is not expressed in the stroma (Robinson et al., 1999). Arachidonic acid has therefore been proposed to act as a paracrine signal released during the oestrous cycle by epithelial cells to induce COX-2 in the stroma (Sheldrick et al., 2007). The experiments described here were carried out to investigate the pathways by which PUFAs induce $C O X-2$ gene expression in endometrial stromal cells.

Previous experiments on the mechanism by which arachidonic acid raises COX-2 levels suggest that peroxisome-proliferator-activated receptors (PPARs) mediate PUFA-induced COX-2 expression in the bovine endometrium (MacLaren et al., 2006; Sheldrick et al., 2007). The isoform PPAR $\alpha$ appears to be involved in bovine endometrial stromal cells. PPAR $\alpha$ is activated directly by a range of PUFAs, including arachidonic acid. However, PPAR $\alpha$ function is dependent on phosphorylation by protein kinase C (PKC; Blanquart et al., 2004), which is also activated by PUFAs (Shinomura et al., 1991; Khan et al., 1995). Furthermore, in some 
91 and Wiltbank, 2001; Yan et al., 2002). As a result arachidonic acid may potentially induce

$92 \mathrm{COX}-2$ directly via PPAR $\alpha$ and indirectly through $\mathrm{PKC} / \mathrm{NF}-\kappa \mathrm{B}$.

94 To distinguish between PPAR-dependent and -independent pathways we have used a reporter

95 construct under the control of a naturally-occurring sequence derived from the bovine $C O X-2$

96 promoter. This construct, which includes most of the important transcription regulators present

97 in the $C O X-2$ promoter but lacks an identifiable peroxisome-proliferator response element

98 (PPRE), allows the study of pathways to COX-2 induction in which PPARs are not involved.

99 Furthermore we have investigated the role of $\mathrm{NF}-\kappa \mathrm{B}$ in the function of the promoter by

100 sequential removal of the NF- $\mathrm{BB}$ sites from this construct.

101

102

MATERIALS AND METHODS

103

\section{Materials}

105 All PUFAs; synthetic PPAR agonists; the NSAIDs, indomethacin and NS398; prostaglandin $106 \mathrm{~A}_{1}\left(\mathrm{PGA}_{1}\right)$; the phorbol ester 4 $\beta$-PMA and its inactive analogue 4 $\alpha$-phorbol 12,13-didecanoate (4 $\alpha$-PDD); the protein kinase C inhibitor, RO 318425, and the NF- $\kappa B$ inhibitor, MG132 were obtained from either Sigma (Poole, UK) or Calbiochem (Nottingham, UK). Conjugated

109 linoleic acid (Sigma catalogue number O 5507) was a mixture of cis- and trans-9,11- and 110 10,12-octadecadienoic acids. The PUFAs, indomethacin and prostaglandins were dissolved in 111 ethanol; all other compounds were added to culture medium in DMSO. Vehicle controls were 112 used as appropriate. PUFAs were stored in ethanol under $\mathrm{N}_{2}$ at $-20^{\circ} \mathrm{C}$ in darkness.

\section{Cell culture}

115 Bovine endometrial stromal cells isolated on day 16 of the oestrous cycle (Flint et al., 2002) 116 were maintained as described previously (Sheldrick et al., 2007). To test effects of PUFAs on 117 COX-2 promoter function, the fatty acids were added to culture medium for up to $48 \mathrm{~h}$ after 118 transfection.

\section{COX-2 reporter plasmids}

121 A bovine COX-2 promoter fragment was cloned by PCR on the basis of the genomic sequence

122 (GenBank accession no. AF031699; Liu et al., 1999). The PCR product was sequenced to 123 confirm its identity, and inserted into the vector pCAT promoter 3 (Promega, Southampton, 
124 UK). The resulting construct was designated pCATCOXprom. This promoter sequence did not contain a PPRE (which is further upstream of the transcription start site; Meade et al., 1999). NF- $\kappa$ B mutants (Lee et al., 2001) were prepared from pCATCOXprom by site directed mutagenesis using the QuikChange multi site-directed mutagenesis kit (Stratagene, Cambridge, UK) and checked by sequencing. The NF- $\kappa$ B consensus sequence GGGAATTCCC at -472 (numbering from the transcription start site) and the related sequence GGAACGTCCC at -454 were both mutated to GGCCTTCCC in separate plasmids (designated Del I and Del II respectively). A third plasmid (Del I/II) contained both mutated sequences. All deletions were confirmed by sequencing. pCAT basic and pCAT control vectors (Promega) were used as controls.

\section{Transient transfections}

Stromal cells at 50-60\% confluence were washed and trypsinized before resuspension in Dulbecco Modified Eagles Medium (DMEM; Sigma, Poole, UK). They were then electroporated at 300 volts, $1650 \mu \mathrm{F}$ with $5 \mu \mathrm{g}$ plasmid DNA in a volume of $0.8 \mathrm{ml}$ DMEM, at a concentration of $1-3 \times 10^{6}$ cells per $\mathrm{ml}$ (conditions which had been optimized in preliminary experiments). Electroporated cells were suspended in DMEM containing 1\% antibioticantimycotic and $10 \%$ fetal bovine serum previously stripped with dextran-coated charcoal (5\% $\mathrm{w} / \mathrm{v}$; DMEMSS) and transferred to 24 -well plates $\left(1.0-1.5 \times 10^{5}\right.$ cells per well). Test compounds were then added to the medium as required, and culture continued for 36 or $48 \mathrm{~h}$. For time course experiments compounds were added at various times before the end of culture; thus in the case of cells treated for $3 \mathrm{~h}$, compounds were added $3 \mathrm{~h}$ before culture was terminated at $48 \mathrm{~h}$ after medium change. At the end of culture cells were washed once in $1 \mathrm{ml}$ ice-cold phosphate-buffered saline containing $0.2 \mathrm{mM}$ sodium orthovanadate and lysed for 20 min on ice with reporter lysis buffer (100-200 $\mu \mathrm{l}$; Promega) for assay of chloramphenicol acetyl transferase and protein.

\section{Chloramphenicol acetyl transferase assay}

Chloramphenicol acetyl transferase (CAT) was measured in cell lysates by a 2 phase method. Pre-cleared cell lysates $(30 \mu \mathrm{l})$ were incubated at $37^{\circ} \mathrm{C}$ with $10 \mu \mathrm{l} 5 \mathrm{mM}$ chloramphenicol in $250 \mathrm{mM}$ Tris containing $5 \mathrm{mM}$ EDTA, pH 7.8 in 96-well plates. After 5 min, $10 \mu \mathrm{l} 75 \mu \mathrm{M} \mathrm{HCl}$ containing $1.5 \mathrm{nmol}\left[{ }^{3} \mathrm{H}\right]$ acetylcoenzyme A (Amersham, Little Chalfont, UK) was added to each tube. The plates were incubated at $37^{\circ} \mathrm{C}$ for $3 \mathrm{~h}$. The reaction mixture (48 $\left.\mu \mathrm{l}\right)$ was 
transferred to scintillation vials containing $0.5 \mathrm{ml} 7 \mathrm{M}$ urea and $5 \mathrm{ml} 0.8 \% \mathrm{w} / \mathrm{v}$ toluene-PPO

158 was added to each vial. The vials were capped and shaken for 15 sec.

$159\left[{ }^{3} \mathrm{H}\right]$ Acetylchloramphenicol extracted into the toluene out of the aqueous phase was measured

160 by scintillation counting after $20 \mathrm{~min}$.

\section{Immunoblotting}

163 Cells were lysed and extracted for immunoblotting as described previously (Sheldrick et al., 164 2007). For immunoblotting, boiled lysates (10 $\mu$ g protein) were subjected to electrophoresis on $16510 \%$ acrylamide gels (5\% stacking gels) before electroblotting onto Protran BA83 (Schleicher 166 \& Schuell, Anderman and Company Kingston-upon-Thames, Surrey, UK) membranes in 25 $167 \mathrm{mM}$ Tris $\mathrm{pH} 8.3$ containing $148 \mathrm{mM}$ glycine and 20\% (v/v) methanol. For detection of COX-2 168 bands (at molecular mass $=72 \mathrm{kDa})$, membranes were probed with COX-2 antibody (C-20; SC 169 1745, Santa Cruz Biotechnology, obtained through Autogen Bioclear, Calne, UK; 1:250 170 dilution in a solution containing 1\% (w/v) Marvel milk powder and 0.5\% (w/v) Tween 20 in 171 phosphate buffered saline). Second antibody was donkey anti-goat IgG-horseradish peroxidase 172 (SC 2020; Santa Cruz Biotechnology; 1:11 000 dilution in 3\% (w/v) Marvel, 0.5\% (w/v) 173 Tween 20 in phosphate buffered saline), and visualization was by enhanced 174 chemiluminescence (Amersham) using Kodak BioMax Light film. Colour markers (molecular 175 masses 29000 - 205 000; Sigma) were used to identify molecular masses of proteins. Band 176 intensities were quantified using Kodak 1D digital image analysis software.

\section{Protein assay}

179 Protein concentrations in lysates prepared for electrophoresis were measured before the 180 addition of $\beta$-mercaptoethanol and bromophenol blue using BCA reagents (Perbio Science, 181 Cramlington, UK; Bradford, 1976).

\section{Experimental design and analysis}

184 Experimental treatments were carried out in 24-well plates, with each replicate treatment of cells in at least 3 wells. Within each experiment all cells were transfected in a single batch

186 before transfer to 24 -well plates, and as a result there were no differences between wells in 187 transfection efficiency. Data were therefore expressed in terms of cell protein, and not 188 corrected for transfection efficiency. To account for differences in band intensity between 189 immunoblots, all blots included 2 control samples, and all experimental treatments were related 
190 to the control bands. All bands were included for analysis. Statistical analysis of treatment

191 effects was by analysis of variance using Genstat version 8 (Lawes Agricultural Trust; obtained

192 through VSN International Ltd, Hemel Hempstead, UK). Where significant effects were

193 detected $(\mathrm{P}<0.05)$ individual differences were tested using a post-hoc test (Bonferroni's

194 multiple comparison test). Values are given as means \pm s.e.m of results of separate

195 experiments. In the figures significant treatment effects (from controls or zero-time treatments)

196 are indicated by different letters above bars.

\section{RESULTS}

\section{Structure of the COX-2 promoter}

The nucleotide sequence of the bovine $C O X-2$ gene promoter is shown in Fig. 1. PPARs form

202 heterodimers with the 9-cis retinoic acid receptor (RXR) to activate target genes by binding to 203 specific response elements (PPREs). PPREs contain two direct repeats of PuGGTCA half-sites 204 separated by one base (usually A) with an additional 4 bases (usually AACT) comprising the 5' 205 part of binding site, giving the consensus sequence AACTAGGNCAAAGGTCA (the hexameric 206 half-sites being italicised; Ijpenberg et al., 1997). The 5' half of this response element is 207 occupied by a PPAR, the 3' half binding the RXR. The bovine $C O X-2$ promoter region 208 contains a group of potential half-binding sites (Fig. 1), but the bovine equivalent of the human 209 COX-2 PPRE, which is $3.9 \mathrm{~kb}$ upstream of the transcription start site (Meade et al., 1999), was 210 not present. A sequence (AAGAGGGGGAAAAGTTT) resembling the PPRE of human 211 lipoprotein lipase (AAGAGGGGGAAAGGGCA; Ijpenberg et al., 1997) is located -109 bp 212 upstream of the translation start site in the bovine sequence. This has a perfect 5' PPAR 213 binding motif, but differs in the last 5 nucleotides from the consensus RXR binding motif. 214 However, as shown below, none of these motifs conferred responsiveness to PPAR $\alpha$ in stromal 215 cells, possibly because there was insufficient homology with actual PPREs, because there are 216 species differences between bovine and other consensus sequences, or because of the proximity 217 of the site at -109 to the transcription start site.

\section{pCATCOXprom was not responsive to PPAR activation}

220 As anticipated due to the absence of a PPRE, and in contrast to the effects of PPAR agonists on 221 endogenous $C O X-2$ gene expression (Sheldrick et al., 2007), the COX-2 promoter was not 222 responsive to the PPAR $\alpha$ agonists ciprofibrate, methylclofenapate, indomethacin, NS398 or 223 prostaglandin $A_{1}$ or to the PPAR $\gamma$ agonist pioglitazone (Fig. 2). Nonetheless arachidonic acid 
224 did induce CAT expression, indicating the presence of a PPAR-independent pathway for COX-

225 2. The response to PUFA varied between experiments in the range 2.0- to 16.2-fold (mean, 6.1-

226 fold; $\mathrm{N}=10$ ). In previous experiments measuring endogenous COX-2 protein, ciprofibrate was

227 as effective a PPAR agonist as WY14643, suggesting that the failure to induce CAT expression

228 was unlikely to reflect poor bioavailability.

\section{Time course of effects of PUFAs on CAT expression}

231 Further evidence that the effect of arachidonic acid (Fig. 2) was not due to activation of a 232 PPAR was obtained from time course studies. At concentrations above $10 \mu \mathrm{M}$, arachidonic 233 acid increased CAT expression between 12 and $24 \mathrm{~h}$ after addition (Fig. 3a). Similar responses 234 were observed with n-6 PUFAs other than arachidonic acid (Fig. 3b), although these were 235 delayed until $24-36 \mathrm{~h}$. In contrast, induction of the endogenous $C O X-2$ gene (as indicated by 236 immunoblotting) peaked at $6 \mathrm{~h}$ after exposure to agonist (Fig. 3a; data of Sheldrick et al., 237 2007). The lag before expression of CAT relative to induction of the endogenous COX-2 238 protein did not reflect the time taken by the cells to recover from electroporation, as the PPAR 239 agonist indomethacin raised COX-2 levels within $6 \mathrm{~h}$ in cells that had been electroporated (Fig. $2403 \mathrm{c})$.

242 Involvement of PKC and NF-אB in induction of CAT expression

243 To further differentiate between PPAR-dependent and -independent effects, two experimental 244 strategies were used to define the roles of $\mathrm{PKC}$ and $\mathrm{NF}-\kappa \mathrm{B}$ in pathways to COX-2 induction.

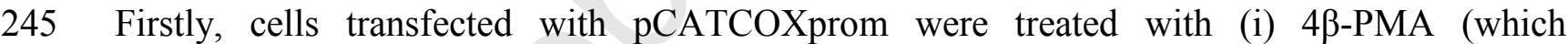
246 specifically activates PKC; Nishizuka, 1984), (ii) prostaglandin $\mathrm{F}_{2 \alpha}$ (which activates PKC 247 though the FP receptor and phospholipase C; Abayasekara et al., 1993), (iii) the PKC inhibitor 248 RO318425, or (iv) the NF- $\mathrm{BB}$ inhibitor MG132 (Wu et al., 2004). Secondly, cells were

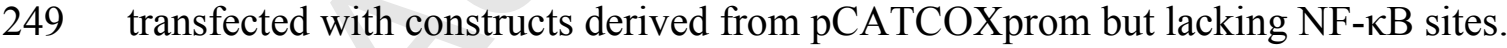

251 Expression of pCATCOXprom was induced by $4 \beta$-PMA and prostaglandin $\mathrm{F}_{2 \alpha}$ (Fig. 4a). When 252 these compounds were added with arachidonic acid the effects of arachidonic acid and $4 \beta-$ 253 PMA or arachidonic acid and prostaglandin $\mathrm{F}_{2 \alpha}$ were additive but not synergistic (i.e. there was 254 no statistically significant interaction). The inactive phorbol ester $4 \alpha$-phorbol 12,13255 didecanoate $(2 \mu \mathrm{M})$ was ineffective. Consistent with a role for NF- $\kappa \mathrm{B}$, the effects of

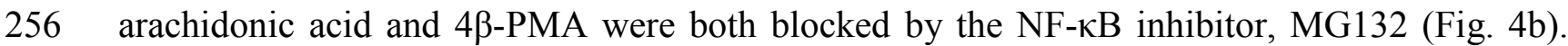
257 MG132 also blocked induction of CAT expression by PGF $_{2 \alpha}$ (data not shown) and reduced 
basal CAT expression when added alone. In contrast to the effect of MG132, the specific PKC

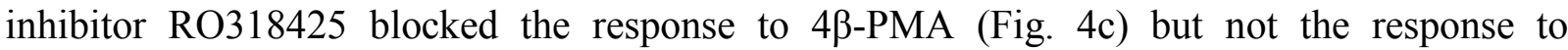
arachidonic acid (Fig. 4d).

In experiments to test the effects of PUFAs on the COX-2 promoter following NF- $\mathrm{KB}$ site deletion, arachidonic acid failed to induce CAT expression in any of the three NF- $\kappa \mathrm{B}$ mutant

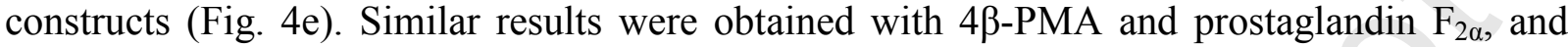
with dihomogammalinolenic, linoleic and conjugated linolenic acids (data not shown). As expected on the basis of the effect of MG132 observed in Fig. 4b, removal of the NF- $\kappa$ B sites from pCATCOXprom reduced basal CAT expression by the constructs to below $1 \%$ of the control level.

\section{DISCUSSION}

271 Previous experiments showed that one pathway to induction of COX-2 in uterine stromal cells treated with arachidonic acid involves PPAR $\alpha$ (Sheldrick et al., 2007). However in previous experiments it was not possible to distinguish between an effect of arachidonic acid as a PPAR agonist and that involving activation of PKC and NF- $\mathrm{BB}$. Inhibitors were used to block either PKC or NF- $\mathrm{BB}$, but blocking PKC led to inhibition of the PPAR pathway (as expected based on the requirement for PPARs to be phosphorylated by PKC; Blanquart et al., 2004).

277 Furthermore the PPAR $\alpha$ antagonist MK886 was ineffective in uterine stromal cells (Sheldrick 278 et al., 2007). As a result it was difficult to identify PPAR-independent pathways. This difficulty has been avoided in the present experiments by using a reporter construct which is unresponsive to PPARs. As a PPAR-responsive reporter construct was not available (the PPRE not being identified to date in the bovine gene), endogenous COX-2 expression acted as a positive control.

284 The results reported here confirm the involvement of PPARs in COX-2 induction, as the synthetic PPAR agonists ciprofibrate, methylclofenapate, indomethacin and NS398, which

287 CAT construct. However the data revealed at least one PPAR-independent pathway for 288 induction of $C O X-2$ promoter function by PUFAs, as the $C O X-2$ promoter construct used was 289 induced by arachidonic acid and other unsaturated fatty acids (Fig. 3a and b). This was 290 confirmed by the time course of CAT induction by PUFAs (occurring at 12 - 48 h; Fig. 3), 291 which differed from that of the endogenous $C O X-2$ gene observed by immunoblotting (which 
292 peaked at $6 \mathrm{~h}$ ). The delay in expression of CAT by PUFAs was not due to damage caused to 293 the cells during electroporation, as expression of COX-2 from the endogenous gene was 294 induced in electroporated cells at $6 \mathrm{~h}$ by indomethacin, which has previously been shown to be 295 an effective PPAR agonist.

297 One potential PPAR-independent route to COX-2 induction involves PKC and NF-кB (Scheme 298 1). All three PKC activators tested here: PUFAs (Shinomura et al., 1991; Khan et al., 1995), 4ß-PMA (Nishizuka, 1984) and prostaglandin $\mathrm{F}_{2 \alpha}$ (Abayasekara et al., 1993) induced CAT expression, and each of these effects was blocked by the NF- $\kappa \mathrm{B}$ inhibitor, MG132. Furthermore the role of NF- $\mathrm{BB}$ was confirmed by the deletion studies which showed that induction of the $C O X-2$ promoter by arachidonic acid, $4 \beta-\mathrm{PMA}$ or prostaglandin $\mathrm{F}_{2 \alpha}$ depended on the presence of an NF- $\mathrm{BB}$ responsive element. These findings are consistent with pathways $\mathrm{c}, \mathrm{d}$, e and $\mathrm{f}$ in Scheme 1.

The effects of arachidonic acid and 4 $\beta$-PMA on CAT expression were also prevented by the I$\kappa \mathrm{B}$ kinase inhibitor parthenolide ( $4 \mu \mathrm{M}$; data not shown). Parthenolide maintains $\mathrm{I}-\kappa \mathrm{B}$ in the non-phosphorylated state, and as a result inhibits translocation of NF- $\kappa \mathrm{B}$ to the nucleus (Bork et al., 1997). Its action is therefore similar to that of MG132, which reduces the rate of I- $\mathrm{B}$ degradation. However, in contrast to the effect of MG132, parthenolide increased basal CAT expression. Among the non-specific effects of sesquiterpene lactones such as parthenolide is the inhibition of 5-lipoxygenase (Capasso, 1986; Sumner et al., 1992). As lipoxygenase products down-regulate COX-2 (Ait-Said et al., 2003), and the lipoxygenase inhibitor nordihydroguaiaretic acid increases COX-2 levels in stromal cells (E.L.R. Sheldrick, unpublished work), an increase in CAT expression in response to parthenolide may reflect a side effect of this compound.

The NF- $\kappa$ B inhibitor MG132 decreased CAT expression dramatically, and deletion of NF- $\mathrm{B}$ sites from pCATCOXprom had the same effect. These effects reflect the importance of NF-kB in regulating $C O X-2$ promoter function. A reduction in basal $C O X-2$ promoter function also follows NF- $\mathrm{kB}$ site mutation in human endometrial stromal cells (Tamura et al., 2002) and alveolar epithelial cancer cells (Huang et al., 2003). The reduced level of CAT in these experiments suggests that a small increase in reporter expression in response to arachidonic acid or $4 \beta$-PMA would have been detectable, had there been an alternative activatory site. The 
325 double mutant was less active than either of the single mutants, but was not induced significantly by PUFA.

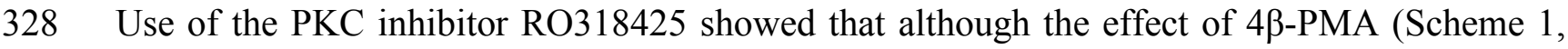
329 pathway e, f) was dependent on PKC, the effect of arachidonic acid was not. This allowed the 330 effect of arachidonic acid to be dissociated from PKC, revealing a PKC-independent pathway 331 to NF- $\kappa \mathrm{B}$ activation by arachidonic acid (pathway $\mathrm{g}$ in Scheme 1). The existence of a PKC332 independent pathway is consistent with the additive effects of arachidonic acid and PKC 333 activators (Fig. 4a). Potential intermediates in this pathway include reactive oxygen species,

334 which are involved in the activation of NF- $\mathrm{B}$ by PUFAs with a time course consistent with 335 that observed here (24 - 48 h; Mazière et al., 1999; Bécuwe et al., 2003). The effect of 336 arachidonic acid was blocked by inhibition of NF-кB (Fig. 4b), ruling out an arachidonic acid337 stimulated pathway to COX-2 induction independent of both PKC and NF-kB.

339 Certain isoforms of PKC are down-regulated following activation, leading to refractoriness 340 (Standeart et al., 1993). In separate studies we have confirmed that this occurs in bovine 341 endometrial stromal cells exposed to $4 \beta$-PMA for $24 \mathrm{~h}$, as shown by a reduction in 342 phosphorylation by PKC of cyclic AMP phosphodiesterase (Cheng et al., 2007). PKC would 343 therefore be expected to be down-regulated following activation by arachidonic acid. On this 344 basis, if the PPAR-independent induction of CAT expression by arachidonic acid required 345 PKC activation, the effect might be expected to be lost after $24 \mathrm{~h}$. The fact that it was not (as 346 the effects of PUFAs were only observed at or after 24 h; Fig. 3) at first sight confirms the 347 suggestion that this effect is not exerted via PKC. However this conclusion is difficult to 348 reconcile with the action of $4 \beta$-PMA, which increased CAT expression at $48 \mathrm{~h}$, the effect being 349 blocked by RO318425 (Fig. 4c). One possible explanation is that the isoform of PKC 350 responsible for CAT induction by $4 \beta$-PMA was resistant to down-regulation by phorbol ester. 351 There is a precedent for this in that PKC isoforms differ in the speed and extent of their down352 regulation by phorbol esters in a cell-specific manner (Adams and Gullick, 1989; Standaert et 353 al., 1993). There are therefore 3 reasons for concluding that PKC is not involved in the 354 response to arachidonic acid: (i) the response is not blocked by RO318425; (ii) the responses to

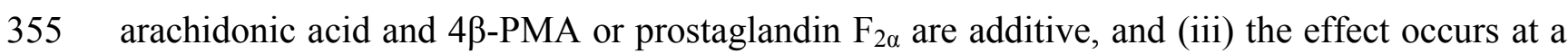
356 time when PKC would be expected to be down-regulated. In the light of these findings we 357 conclude that arachidonic acid activates COX-2 promoter function in the absence of a PPRE, 
358 demonstrating the existence of a PPAR-independent route to COX-2 expression, and that NF$359 \kappa \mathrm{B}$ (but not PKC) is involved in this response.

360

361

362

363

364 We thank Pat Fisher for isolating the endometrial stromal cells. This work was funded by the

365 Biotechnology and Biological Sciences Research Council and the Wellcome Trust. 
Abayasekara, D.R.E., Jones, P.M., Persaud, S.J., Michael, A.E., Flint, A.P.F., 1993. Prostaglandin $\mathrm{F}_{2 \alpha}$ activates protein kinase $\mathrm{C}$ in human ovarian cells. Mol. Cell. Endocrinol. 91, 51-57.

Adams, J.C., Gullick, W.J., 1989. Differences in phorbol-ester-induced down-regulation of protein kinase C between cell lines. Biochem. J. 257, 905-911.

Ait-Said, F., Elalamy, I., Werts, C., Gomard, M.-T., Jacquemin, C., et al., 2003. Inhibition by eicosapentanoic acid of IL-1 $\beta$-induced PGHS-2 expression in human microvascular endothelial cells: involvement of lipoxygenase-derived metabolites and p38 MAPK pathway. Biochim. Biophys. Acta 1631, 77-84.

Asselin, E., Drolet, P., Fortier, M.A., 1997. Cellular mechanisms involved during oxytocininduced prostaglandin $\mathrm{F}_{2 \alpha}$ production in endometrial epithelial cells in vitro: role of cyclooxygenase-2. Endocrinology 138, 4798-4805.

Bécuwe, P., Bianchi, A., Didelot, C., Barberi-Heyob, M., Dauça, M., 2003. Arachidonic acid activates a functional AP-1 and an inactive NF- $\kappa \mathrm{B}$ complex in human HepG2 hepatoma cells. Free Radical Biol. Med. 35, 636-647.

Blanquart, C., Mansouri, R., Paumelle, R., Fruchart, J.-C., Staels, B., et al., 2004. The protein kinase $\mathrm{C}$ signaling pathway regulates a molecular switch between transactivation and transrepression activity of the peroxisome proliferator-activated receptor $\alpha$. Mol. Endocrinol. 18, 1906-1918.

Bork, P.M., Schmitz, M.L., Kuhnt, M., Escher, C., Heinrich, M., 1997. Sesquiterpene lactone containing Mexican Indian medicinal plants and pure sesquiterpene lactones as potent inhibitors of transcription factor NF-кB. FEBS Lett. 402, 85-90.

Bradford, M.M., 1976. A rapid and sensitive method for the quantitation of microgram quantities of proteins utilizing the principle of protein-dye binding. Anal. Biochem. 72, 248-254. 
Capasso, F., 1986. The effect of an aqueous extract of Tanacetum parthenium L. on arachidonic acid metabolism by rat peritoneal leucocytes. J. Pharm. Pharmacol. 38, 71-71.

Cheng, Z., Sheldrick, E.L., Marshall, E., Wathes, D.C., Abayasekara, D.R.E., et al., 2007. Control of cyclic AMP concentration in bovine endometrial stromal cells by arachidonic acid. Reproduction 133, 1017-1026.

Cooke, B.A., Dirami, L., Chaudry, L., Choi, M.S.K., Abayasekara, D.R.E., et al., 1991. Release of arachidonic acid and the effects of corticosteroids on steroidogenesis in rat testis Leydig cells. J. Steroid Biochem. Mol. Biol. 40, 465-471.

Flint, A.P.F., Sheldrick, E.L., Fisher, P.A., 2002. Ligand-independent activation of steroid receptors. Dom. Anim. Endocrinol. 23, 13-24.

Flint, A.P.F., Leat, W.M.F., Sheldrick, E.L., Stewart, H.J.. 1986. Stimulation of phosphoinositide hydrolysis by oxytocin and the mechanism by which oxytocin controls prostaglandin synthesis in the ovine endometrium. Biochem. J. 237, 797-805. requirement of peroxisome proliferator-acivated receptor (PPAR)/RetinoidX receptor

Huang, W.-C., Chen, J.-J., Inoue, H., Chen, C.-C., 2003. Tyrosine phosphorylation and I$\kappa \mathrm{B}$ kinase $\alpha / \beta$ by protein kinase $\mathrm{C}$-dependent $\mathrm{c}$-Src activation is involved in TNF- $\alpha$ heterodimer binding to DNA. J. Biol. Chem. 272, 20108-20117.

Khan, W.A., Blobe, G.C., Hannun, Y.A., 1995. Arachidonic acid and free fatty acids as 
Liu, J., Antaya, M., Boerboom, D., Lussier, J.G., Silversides, D.W., et al., 1999. The delayed activation of the prostaglandin $\mathrm{G} / \mathrm{H}$ synthase-2 promoter in bovine granulosa cells is associated with down-regulation of truncated upstream stimulatory factor-2. J. Biol. Chem. 274, 35037-35045.

MacLaren, L.A., Guzeloglu, A., Michel, F., Thatcher, W.W., 2006. Peroxisome proliferator-activated receptor (PPAR) expression in cultured bovine endometrial cells and response to omega-3 fatty acid, growth hormone and agonist stimulation in relation to series 2 prostaglandin production. Dom. Anim. Endocrinol. 30, 155-169.

Mazière, C., Conte, M.-A., Degonville, J., Ali, D., Mazière, J.-C., 1999. Cellular enrichment with polyunsaturated fatty acids induces an oxidative stress and activates the transcription factors AP1 and NFkB. Biochem. Biophys. Res. Comm. 265, 116-122.

Maloberti, P., Castilla, R., Castillo, F., Maciel, F.C., Mendez, C.F., et al., 2005. Silencing the expression of mitochondrial acyl-CoA thioesterase I and acyl-synthetase 4 inhibits hormone-induced steroidogenesis. FEBS J. 272, 1804-1814.

Meade, E.A., McIntyre, T.M., Zimmerman, G.A., Prescott, S.M., 1999. Peroxisome proliferators enhance cyclooxygenase-2 expression in epithelial cells. J. Biol. Chem. 274, 8328-8334.

Nishizuka, Y., 1984. The role of protein kinase C in cell surface signal transduction and tumour promotion. Nature, Lond. 308, 693-698. 
Prigent-Tessier, A., Pageaux, J.-F., Fayard, J.-M., Lagarde, M., Laugier, C., et al., 1996. Arachidonic acid up-regulates and prostaglandin $E_{2}$ down-regulates the expression of pancreatic-type phospholipase $\mathrm{A}_{2}$ and prostaglandin-endoperoxide synthase 2 in uterine stromal cells. Eur. J. Biochem. 241, 872-878.

Robinson, R.S., Mann, G.E., Lamming, G.E., Wathes, D.C., 1999. The effect of pregnancy on the expression of uterine oxytocin, oestrogen and progesterone receptors during early pregnancy in the cow. J. Endocrinol. 160, 21-33.

Ronco, A.M., Moraga, P.F., Llanos, M.N., 2002. Arachidonic acid release from rat Leydig cells: the involvement of $\mathrm{G}$ protein, phospholipase $\mathrm{A}_{2}$ and regulation of cAMP production. J. Endocrinol. 172, 95-104.

Sheldrick, E.L.R., Derecka, K., Marshall, E., Chin, E.C., Hodges, L., et al., 2007.

Peroxisome-proliferator-activated receptors and the control of levels of prostaglandinendoperoxide synthase 2 by arachidonic acid in the bovine uterus. Biochem. J. 406, 175 183.

Standaert, M.L., Cooper, D.R., Hernandez, H., Arnold, T.P., Farese, R.V., 1993.

Shinomura, T., Asaoka, Y., Oka, M., Yoshida, K., Nishizuka, Y., 1991. Synergistic action of diacylglycerol and unsaturated fatty acid for protein kinase $\mathrm{C}$ activation: its possible implications. Proc. Natl. Acad. Sciences U.S.A. 88, 5149-5153.

Sumner, H., Salan, U., Knight, D.W., Hoult, J.R.S., 1992. Inhibition of 5-lipoxygenase and cyclo-oxygenase in leukocytes by feverfew. Biochem. Pharmacol. 43, 2313-2320.

Tamura, M., Sebastian, S., Yang, S., Gurates, B., Fang, Z., et al., 2002. Interleukin-1 $\beta$ elevates cyclooxygenase-2 protein level and enzyme activity via increasing its mRNA stability in human endometrial stromal cells: an effect mediated by extracellularly regulated kinases 1 and 2. J. Clin. Endocrinol. Metab. 87, 3263-3273. 
Wu, W.-T., Chi, K.-H., Ho, F.-M., Tsao, W.-C., Lin, W.-W., 2004. Proteosome inhibitors up-regulate haem oxygenase-1 gene expression: requirement of p38 MAPK (mitogenactivated protein kinase) activation but not of NF-kB (nuclear factor $\mathrm{kB}$ ) inhibition. Biochem. J. 379, 587-593.

506

507 Wu, Y.-L., Wiltbank, M.C., 2001. Transcriptional regulation of cyclooxygenase-2 gene in 508 ovine large luteal cells. Biol. Reprod. 65, 1565-1572.

509

510 Yan, X., Xiao, C.W., Sun, M., Tsang, B.K., Gibb, W., 2002. Nuclear factor kappa B 511 activation and regulation of cyclooxygenase type-2 expression in human amnion 512 mesenchymal cells by interleukin-1 $\beta$. Biol. Reprod. 66, 1667-1671. 
516 Figure 1. (a) Fragment of bovine $C O X-2$ gene promoter. Numbering as given in GenBank accession no. $\underline{\mathbf{A F 0 3 1 6 9 9}}$ at left, from the transcription start site (TSS) at right. Throughout this paper, numbering is from the transcription start site. Block arrows mark transcription and translation start sites (indicated by TSS and coding sequence respectively). Thin arrows mark PCR primers used to produce the insert in pCATCOXprom. Half sites of native PPREs (after Ijpenberg et al., 1997) are underlined and highlighted. The almost perfect match to the native PPRE present in the human lipoprotein lipase promoter at position $-109--93$ of the bovine $C O X-2$ promoter sequence is highlighted (13 out of 17 nucleotides being identical). The NF- $\mathrm{KB}$ sites I and II are in bold and underlined. (b) Mutations introduced in both NF-kB sites (Lee et al., 2001).

Figure 2. CAT expression in stromal cells transfected with pCATCOXprom and treated with PPAR agonists. Cells transfected by electroporation were cultured for $36 \mathrm{~h}$ with or without the following PPAR agonists which have previously been shown to raise endogenous COX-2 levels in stromal cells (Sheldrick et al., 2007): ciprofibrate $(50 \mu \mathrm{M})$, methylclofenapate (50 $\mu \mathrm{M})$, indomethacin $(10 \mu \mathrm{M})$, NS398 $(10 \mu \mathrm{M})$ and prostaglandin $\mathrm{A}_{1}(3 \mu \mathrm{M})$. The PPAR $\gamma$ agonist pioglitazone $(50 \mu \mathrm{M})$ has previously been shown to be ineffective. Arachidonic acid, but none of the other PPAR $\alpha$ agonists, induced CAT expression.

Figure 3. Time course of induction of CAT expression by arachidonic acid and other PUFAs. (a) Stromal cells transfected with pCATCOXprom were cultured in the presence of arachidonic acid $(50 \mu \mathrm{M})$ for up to $48 \mathrm{~h}$. Closed bars, CAT expression; open bars, endogenous COX-2

538 determined by immunoblotting in non-transfected cells (data of Sheldrick et al., 2007). COX-2

539 levels were raised at $3-12 \mathrm{~h}$, whereas CAT expression was raised only after $12 \mathrm{~h}$. Inset shows 540 representative immunoblotting signals for COX-2. (b) Specificity of CAT induction by PUFAs. 541 Stromal cells transfected with pCATCOXprom were cultured in the presence or absence of 542 dihomogammalinolenic acid (DGLA; $50 \mu \mathrm{M}$ ), conjugated linoleic acid (CLA; $50 \mu \mathrm{M})$ or 543 linoleic acid (LA; $2 \mu \mathrm{M})$ for up to $48 \mathrm{~h}$. The concentration of linoleic acid tested, $2 \mu \mathrm{M}$, was 544 optimal in dose response experiments (data not shown). (c) Electroporated cells remained 545 responsive to PPAR ligand. To test whether the failure of PPAR ligands to induce COX-2 546 promoter function at $6 \mathrm{~h}$ (Figs. 2 and 3a) reflected damage to cells caused by electroporation, 
cells were cultured with the PPAR ligand indomethacin with (Electroporated) and without (Control) electroporation. COX-2 levels were measured by immunoblotting after $6 \mathrm{~h}$ treatment. Indomethacin increased COX-2 levels both before and after electroporation, showing that expression from the endogenous $C O X-2$ gene at $6 \mathrm{~h}$ was not prevented by electroporation.

552 Figure 4. Induction of CAT expression by arachidonic acid, 4 $\beta$-PMA and prostaglandin $\mathrm{F}_{2 \alpha}$. 553 Stromal cells transfected with pCATCOXprom (or related NF- $\kappa \mathrm{B}$ deletion mutants) were

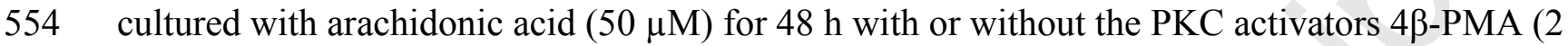
$\mu \mathrm{M})$ and prostaglandin $\mathrm{F}_{2 \alpha}(3 \mu \mathrm{M})$, the PKC inhibitor RO318425 $(500 \mu \mathrm{M})$, the NF- $\mathrm{BB}$ inhibitor MG132 $(30 \mu \mathrm{M})$ or the inactive phorbol ester $4 \alpha$-phorbol 12,13-didecanoate $(2 \mu \mathrm{M})$.

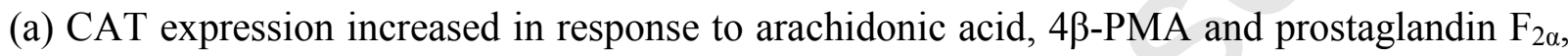
and the effects of arachidonic acid and either $4 \beta$-PMA or prostaglandin $\mathrm{F}_{2 \alpha}$ were additive. $4 \alpha$ Phorbol 12,13-didecanoate (4a-PDD) had no effect. (b) The effects of both arachidonic acid and 4 3 -PMA were prevented by MG132. Note that CAT expression was decreased by MG132

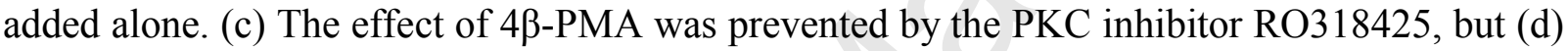
the effect of arachidonic acid was not. (e) The response to arachidonic acid was blocked by deletion of either of the NF- $\kappa \mathrm{B}$ sites in the reporter plasmid pCATCOXprom. Del I, -472/-463 mutation; Del II, -454/-445 mutation; Del I/II, mutations at both $-454 /-445$ and $-472 /-463$. Basal CAT expression in mutation Del I/II was lower than for the other mutant constructs, but the effect of arachidonic acid was not statistically significant.

Scheme 1. Scheme illustrating possible pathways by which arachidonic acid (AA) induces COX-2 expression (or, in reporter experiments, expression of chloramphenicol acetyl transferase, CAT) in stromal cells. AA induces expression of the endogenous $C O X-2$ gene through activation of PPAR $\alpha$ (a) (Sheldrick et al., 2007). Protein kinase C (PKC) activates PPAR a through phosphorylation (b) (Blanquart et al., 2004). These pathways are shown as

573 dotted lines because the COX-2 promoter construct used in the present experiments to express

574 CAT lacked a peroxisome-proliferator-activated receptor response element, and did not respond to PPAR $\alpha$ activation. PKC may be activated directly by AA (c), indirectly by prostaglandin $F_{2 \alpha}$ synthesised from AA via the FP receptor and phospholipase $C$ (d) or by the

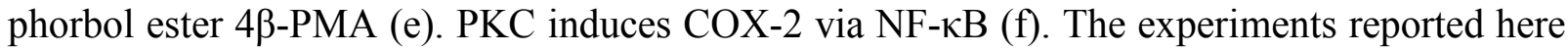

578 suggest a third pathway by which AA induces COX-2 via an unspecified intermediate $\mathrm{X}$ acting

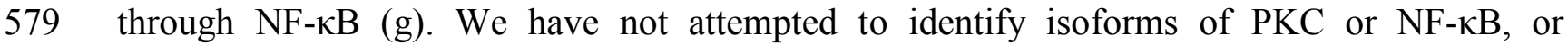


580 intermediates between PKC and NF- $\kappa$ B. After Sheldrick et al. (2007), which provided evidence 581 for pathways a - f, but not for pathway $\mathrm{g}$.

582 


\section{Figure 1}

(a)

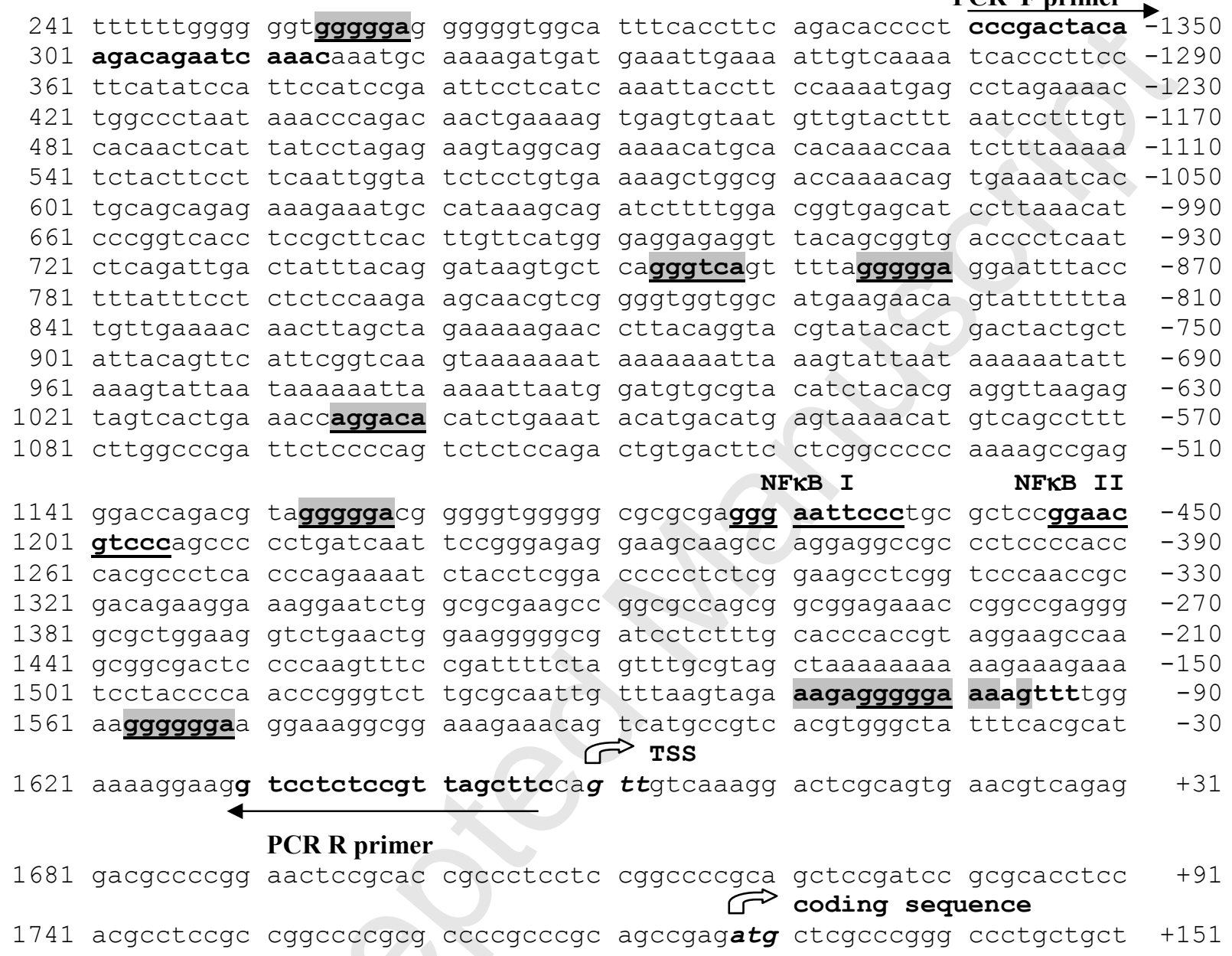

(b)

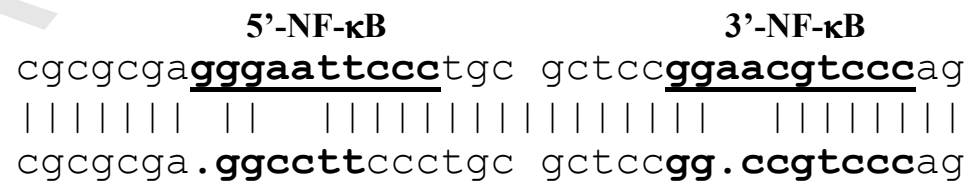


59

60
Figure 2

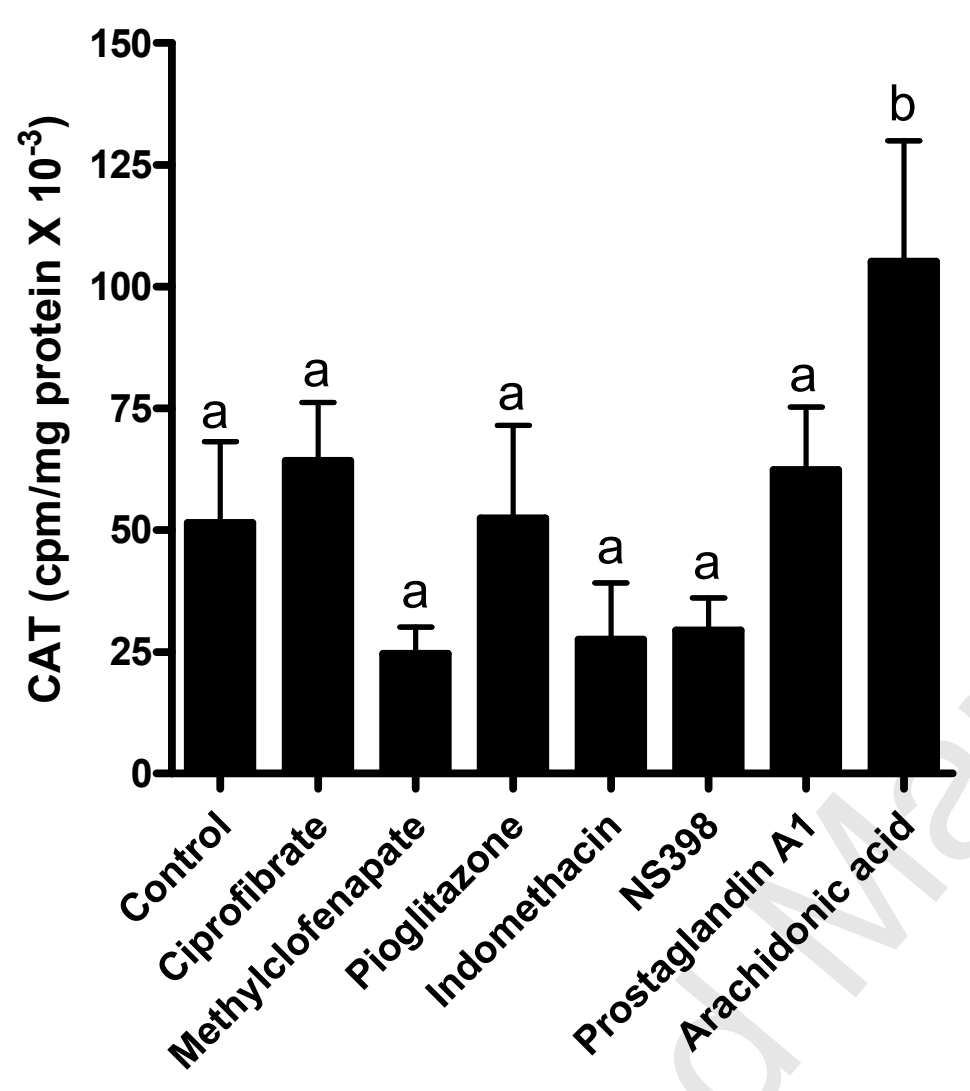


Figure 3

62

63

64

65 (a)

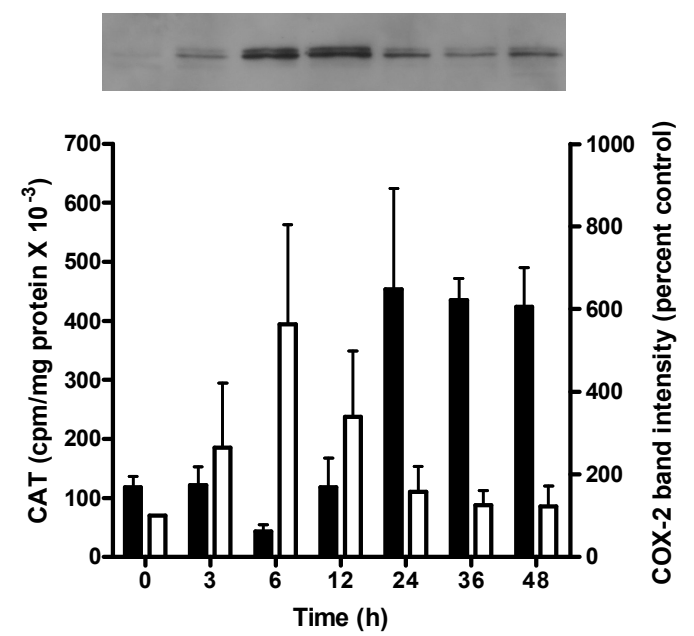

(c)

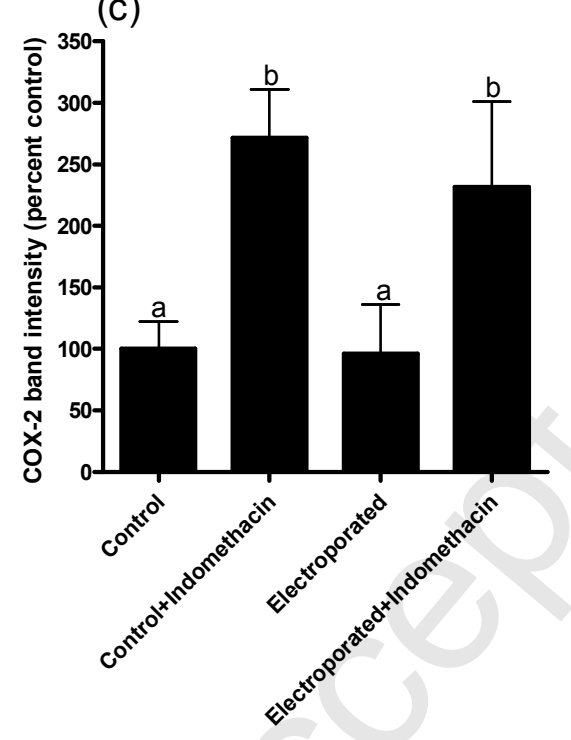

(b) DGLA

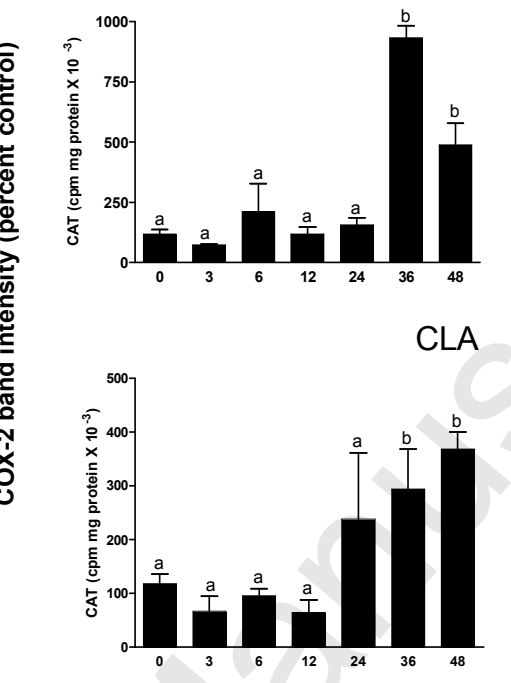

LA

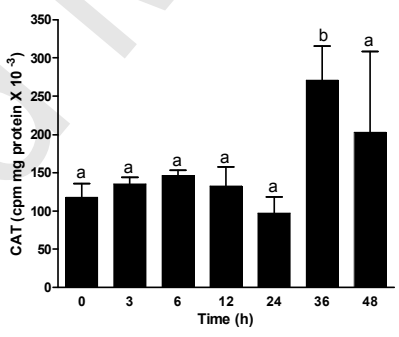

66 
Figure 4

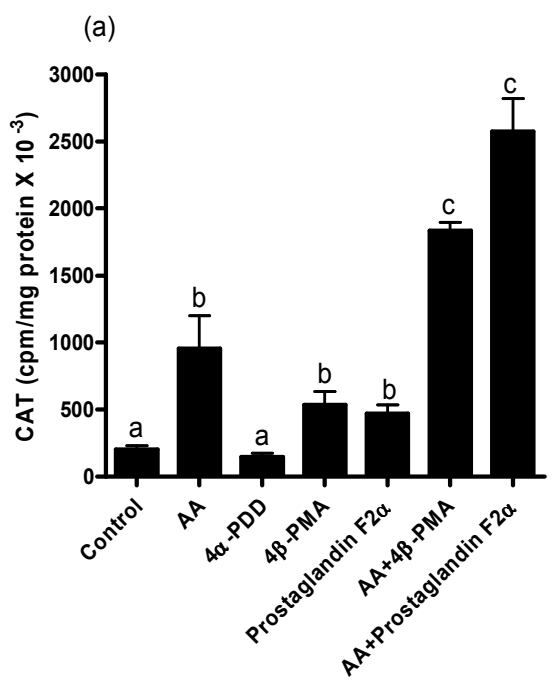

(b)

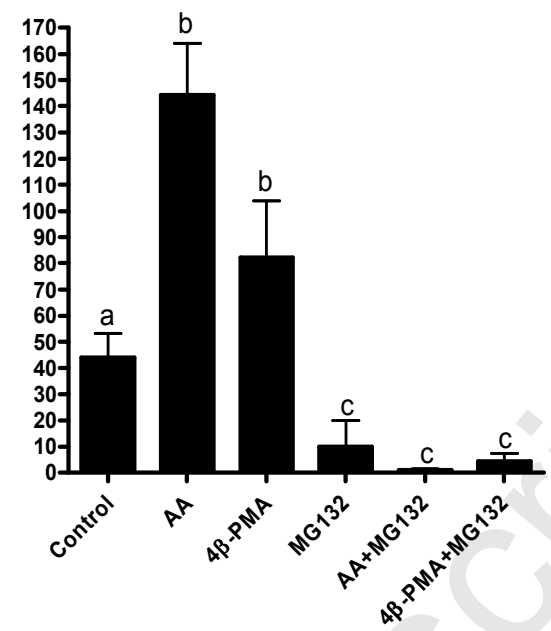

(c)
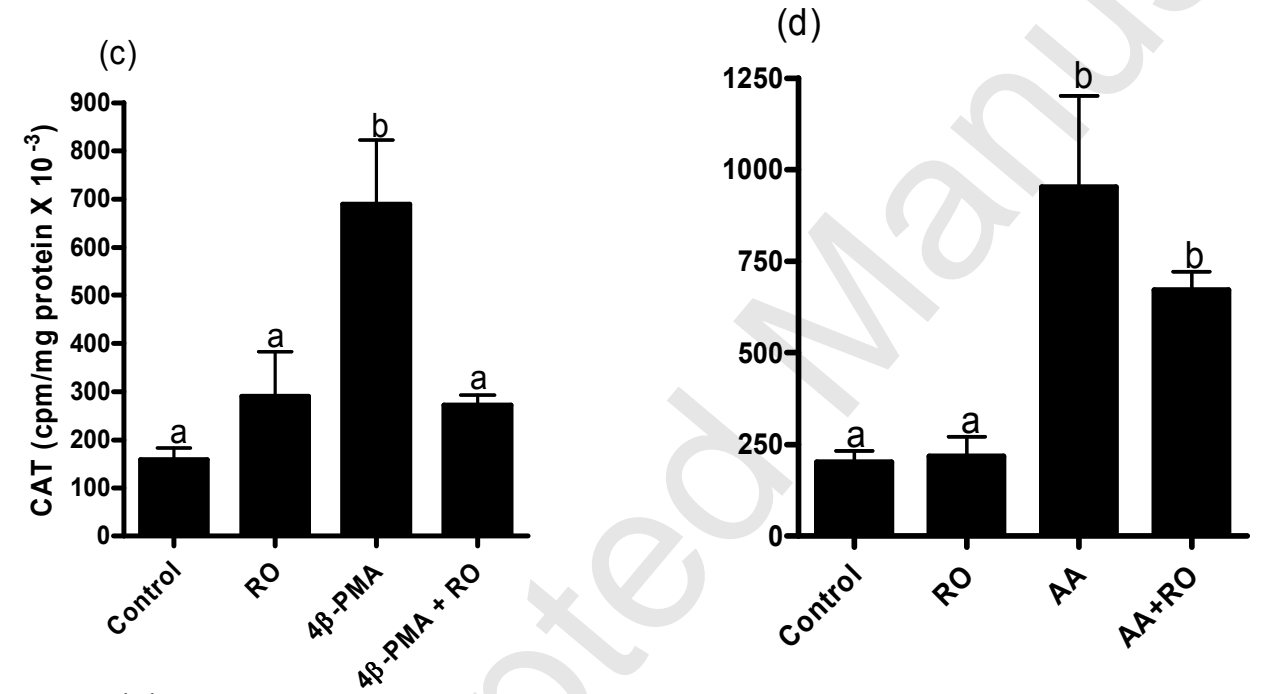

(e)

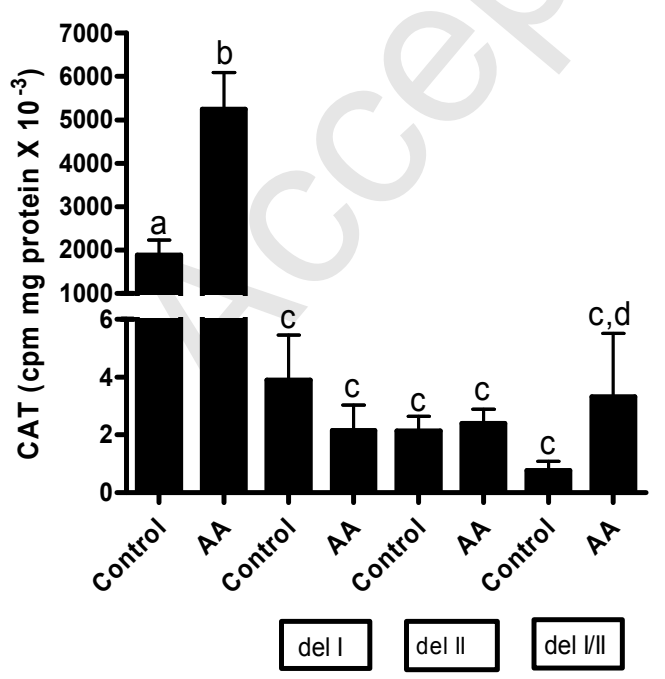




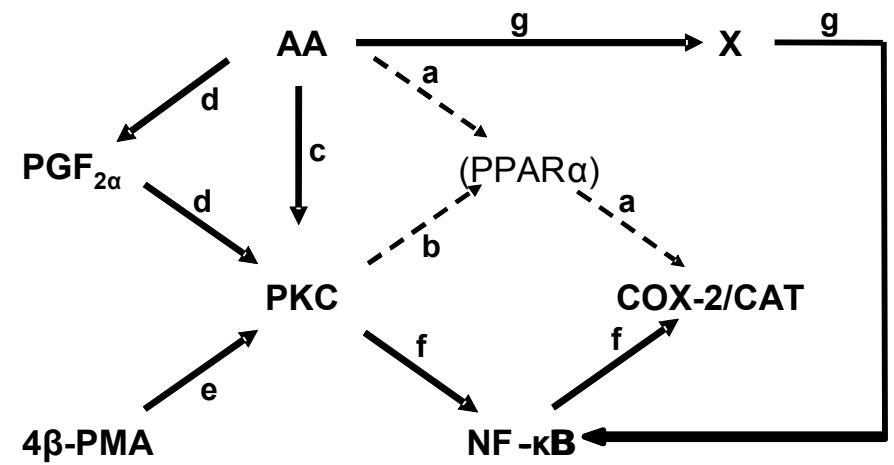

